\title{
Sciendo
}

\section{Locally uniform water utility pricing. Social and economic issues in an emergent policy in France and Italy.}

\author{
Emmanuelle Hellier \\ Prof., Department of Geography and Spatial Planning, Univ Rennes (Rennes University), \\ Spaces and Societies UMR 6590 CNRS, e-mail: emmanuelle.hellier@,univ-rennes2.fr
}

\section{Doi: 10.2478/gssfj-2018-0008}

\begin{abstract}
Over the past twenty years, the principles of 'full-cost recovery' and 'the user pays' have become prominent in water utility pricing across the EU. At the same time, uniform pricing has been introduced by local authorities to boost equality between users in a given territory. Two case studies in France and Italy reveal different processes, depending upon the institutional setting, though in both cases EU regulations exert increasing influence on the water pricing structure. A literature review and study of specific documentation was used to prepare about thirty semi-directive interviews with public owners, private firms, and users' organizations, all conducted face-to-face. The overview presented here has highlighted several trends common to the two case studies, France and Italy, in line with the EU standardization of water pricing structures. The differences arise from different national regulations and territorial models. Local congruence in pricing clearly accompanies reinforced cooperation between municipalities, promoting the legitimacy and visibility of public authorities but inducing complex economic mechanisms such as cross-subsidies and amendments to delegation agreements.
\end{abstract}

Keywords: water utilities, public policy, equal pricing, European Union

\section{Introduction}

\subsection{Social and scholarly debates about water utilities pricing}

Fair public access to water utilities is a major issue for human development goals. Regulatory mechanisms are needed to ensure optimal water tariffs and limit price rises for a vital commodity (Grafton R. et al., 2015). Many policies in various countries have introduced variable pricing depending on the type of user and their standard of living. Paying for water access also raises certain ethical and social issues with regard to human rights. Indeed, outsourcing the local delivery of public services presupposes combining "managerial interests with political responsibility aiming at protecting customers" (Argento et al., 2010, p.43). Thus, many nongovernmental organizations dispute the economic rationale behind privatizing water utilities. They put forward the not-for-profit dimension and "human right to water", notably for southern countries (Motta and Nilsen, 2011). Others NGOs call for a variable tariff depending on consumption volumes (either a progressive tariff or increasing block tariffs (IBTs). This brings with it the risk of inequality, 
undue privileges (Smets, 2013), and other negative consequences (Boland, Whittington, 2000; Rogers et al., 2002).

Faced with these ongoing processes, scholarly debate is open about the advantages of social tariffs and territorially uniform tariffs in developing countries (Boland and Whittington, 2000). The advantages differ depending on the point of view adopted (environmental, social, or economic). In theory price rises may limit consumption but penalize large families. Furthermore, the price elasticity of demand is not significant according to Beecher (1994), quoted in US EPA (2003): "when the price increases, consumption decreases but at a lower rate than the increase in price". A questionnaire survey in Greece found that the impact of household incomes is statistically insignificant, in line with results from similar studies (Kanakoudis, Gonelas, 2014). It is thus hard to ascertain any effect of price structure in offsetting social inequalities. This raises the question of the purpose and benefits of promoting spatial convergence in water pricing. Indeed, the literature points out that single-tariff pricing presents advantages for social cohesion and public policy, as well as for regionalization management and physical interconnections. Single-tariff pricing may promote regional communities structuring, and "encourage managerial capacity" (US EPA, 1999). Clearly, this process is not a "cost strategy" but a "pricing strategy". The same source indicates that uniform price "can appear to lower costs when in reality it simply allocates cost differently". Lastly, some significant economies of scale may accrue from lower transaction costs (US EPA, 1999).

\subsection{Theoretical framework and main issues}

This paper examines the announced social and political advantages of single-tariff water, assessing their significance through two cases studies. The investigation is situated in the spatial and regulatory framework of the European Union. Current EU norms pertaining to full-cost-recovery through utility prices have been in place since 2010, in the form of the Water Framework Directive (WFD) 2000/60/CE. In addition to this, an official $2001 \mathrm{EU}$ Council text states that "everyone has a right to enough water to meet their basic needs"; the introduction to the WFD puts it: "Water is not a good like others" (Bauby and Similie, 2013). The paper works on the assumption that the goal of social equality, combined with the EU's economic principles (of 'user pays', 'polluter pays", and 'full-cost recovery') leads local public authorities to cooperate in "regional communities" (US EPA, 1999). The topic of "a socially fair drinking water pricing policy" is of concern to managers and users-consumers, as well as to researchers (Kanakoudis, Gonelas, 2014). This paper builds on scholarship examining the relationship between water tariffs and public policies, a factor that has attracted increasing interest in economic and territorial issues (Kanakoudis et al., 2016; Garcia-Valiñas, M., Picazo-Tadeo, J. A., 2015; Kanakoudis, Papadopoulpou, Tsitsifli, 2015). 
The theoretical framework draws on political science, using the concepts of governance and policy instruments to analyze changes to the how water utilities are administered (Le Galès, 2010). Le Galès' hypothesis is that "using policy instruments to understand administration implies developing depoliticized formulas pertaining to "the new modes of administration" and reinforcing powerful mechanisms to control and guide behavior" (Le Galès, p.143). The "fair price" issue takes its place within this theoretical framework. Indeed, water pricing is a policy mechanism that is now influenced by regulatory actors and EU experts, on one the one hand, and local elected representatives, public and private owners, and citizen and user organizations on the other. In addition to this, international academic publications by Australian and Canadian scholars, for instance, offer useful insights into water utilities governance. Van de Meene et al. underline how three modes of urban water governance come together in a composite, combining hierarchical governance, market governance, and network governance (Van de Meene et al., 2011). Similarly, Karen Bakker's argues that governance design is based on the triad of state, market, and community (Bakker, 2007). The stakeholders surveyed for this article have to contend with vertical rules (hierarchy, state), while trying to obtain economies of scale (market), building up local and regional coalitions with private firms and customer associations (network).

To this end it provides an overview of water utility pricing as a socio-economic fact, resulting from tradeoffs between stakeholders and framed by EU rules (section 2). The research methods are set out, based in particular on a comparison between two national contexts (section 3). Section 4 presents results from the comparison of empirical data provided by two cases studies. Finally, a concluding discussion sets out the contributions and limits of this empirical approach and suggests further areas of investigation to build on these initial results (section 5).

\section{General tradeoffs in EU water pricing}

\subsection{Pricing and tariffs: economic principles and examples}

Consolidated water prices involve some tradeoffs between economic goals and social needs. Cost-of-service, a research topic for economists, constitutes strategic data for owners, in particular for water supply and sanitation. The same is true of water prices and tariff structures, even though the price is visible on bills. The issue of secrecy is complicated by industrial and technical parameters, such as network length, water quality, and structural costs. In explaining this, researchers refer to the fact that water services are a divided market and a competitive system (Guérin-Schneider and Lorrain, 2003). Although this makes the subject relatively difficult to address, any pitfalls may be overcome with experience in these specific fields (see section 3). Many experts and economic researchers approach water pricing as a logical rule, based on the premise of "true prices" founded on "real costs". For Guérin-Schneider and Lorrain: "whilst all experts concur in noting that 
the final price is independent of the fact that the asset (the water) is free at the beginning of cycle, prices must be closely aligned with costs" (Guérin-Schneider and Lorrain, 2003). For Rogers et al. (2002), the full cost includes the capital charges and management cost (full supply cost), the opportunity cost and the economic externalities (full economic cost), and the environmental externalities (full cost). The European Union encourages member states to adopt full-cost recovery. The United Nations Dublin Conference (1992) recognized that water is a fragile resource and asserted that it is an economic asset that ought to have a price, particularly to limit wastage. At the same time, a growing issue in France, as in northern Europe, is reducing water use (for the largest users and outdoor uses), which in theory at least forces water utilities owners to raise their unit price (Barraqué, 2012). Of course, decreasing water use is not only a result of the owners' policies, and may also be attributable to innovation and to facilities using decreasing amounts of water.

Water utility prices are a socio-political construct, underpinned by these supranational frameworks and on the legitimacy of the "user pays" principle. Furthermore, they vary spatially and historically depending upon stakeholders and national regimes. It needs to be pointed out that water utility pricing is not systematic in all regions of the world. In a municipal distribution network, the water bill may be proportional to the rental value of a housing unit, with its amount fixed by law and integrated in local taxes. In Québec province, for example, water supply has been run by the Montréal public authorities since 1845 and managed as part of the city budget. Proposals to involve the Suez Company in 1999 were rejected (Fougères, 2004, quoted in Melosi, 2012). Equally, water pricing needs to be viewed in a long-term context, stretching back to when water supply was first set up in Europe, at the end of 16th century in London. People's relation to water supply changed during the $18^{\text {th }}$ and $19^{\text {th }}$ centuries. New ownersboth private companies and public authorities-demanded paid subscription. Previously water from standpipes and private wells was free, and carriers were paid a fee for their service. This obligatory annual payment delayed the implementation of water pricing (Defeuilley, 2017). In the contemporary period, communist regimes around the world provided domestic users with free water supply as a vital asset, under a system where the state controlled service provision. Thus water pricing stems from a socio-economic arrangement, supported by institutional and management choices by public authorities, at a national and often local scale, within a reinforced European framework.

\subsection{Public policies in water pricing, territorial and social issues}

On these premises, this paper examines the scope of public policy to harmonize prices and reduce spatial price disparities, against the backdrop of the implementation of EU norms. Some investigations of Greek water supply explain spatial variations in pricing policy. The results highlight the paradox of lowest 
mean payable charges in dry regions, and "water utilities do not speak the same language" (Kanakoudis, Papadopoulpou, Tsitsifli, 2015). Water tariff structures and prices have hitherto differed across countries, regions, and municipalities. The water utility price is an economic value, based on multiple ecological, sociopolitical, and technical factors in a given local territory. What are the policy targets and outcomes in tariff and price harmonization at the local (urban) scale? What processes can be carried out, and what targets met? The financial choices can appear forced, embodying a deliberate strategy going against economic rationale. Above and beyond issues of technical feasibility and financial mechanisms, our analysis looks at courses of action and their outcomes, decoding the reasons, facts, and required effects of this harmonization process, sustained by local authorities working within the European tariff framework.

\section{Methodology and national contexts. An approach based on policy processes and spatial comparison}

\subsection{Two main countries, a long survey}

This paper draws on several field surveys, conducted in several French towns, particularly Rennes (Brittany) over the course of ten years, together with recent investigation in Europe, particularly Arezzo (Toscana). A literature review and study of specific documentation was used to prepare about thirty semi-directive interviews with public owners, private firms, and users' organizations, all conducted face-to-face. The main questions related to management approaches, cost structures, and cooperation with stakeholders to improve service quality. A sizeable majority of interviews were with local politicians, and with agents and managers responsible for water services in France (Rennes was one of five agglomerations surveyed in 2011; https://tel.archives-ouvertes.fr/tel00772279/document). In Tuscany, I interviewed six people in 2017: two managers at the Arno Basin Establishment, the Technical Manager and his deputy at Nuove Acque, and the director and chairman of Consorzio di Bonifica de la ValdiChiana. As already mentioned, it was fairly hard to access local data about water utility pricing, despite technical and administrative reports: annual reports on water utility prices, sustainability, and quality provide useful public information tools at the local level (Nuove Acque, 2016; SPL Eau du Bassin Rennais, 2016). Lastly, the analysis is based on ten years of information gathered by sitting on scientific committees (for example, the Conseil Scientifique de l'Environnement de Bretagne (Brittany Environmental Scientific Council) from 2010 to 2013), attending research reports, and taking part in working meetings and discussions with practitioners (for example, devising a public information circuit at a water treatment plant for Eau du Bassin Rennais, in October 2016), as well as with environmental and user associations (for example, a debate with the Association Legambiente in Arezzo in February 2017). 
The decision to compare two case studies stems both from the research topic and the methodology. The aim is to compare located processes, rooted in specific institutional regimes. It is hence appropriate to analyze only a limited number of case studies. International enquiries into water tariff regulation tend to focus on a single in-depth case study of one country or one town, though some national-scale studies have been conducted for the EU (Euromarket Project, 2005) or even across the EU as a whole (Roth, 2001 for example).

One of the two case studies is located in France, and the other in Italy. These two countries were chosen for having followed fairly similar trajectories in water utility management, but over different timeframes. Some relevant studies have already compared France and Italy (Crespi-Reghizzi, 2013) or else examined the scenario in each of these two countries (Breuil and al., 2005), explaining the institutional framework and the history of water regulations up to the present day. This article focuses on developments in the delegation of water utilities in these two countries (Lupton and Bauby, 2008), mainly in the wake of directives (in 1975 and 1980) to improve water quality standards (table 1). In France, water utilities were transferred to private firms in the 1980s and 1990s, at the same time as responsibility for water utilities was handed over to inter-municipal structures. In Italy, private-public owned companies were set up in the wake of institutional reforms in the 2000s. This shift is characteristic of the trend towards PublicPrivate Partnerships around the world in the 1990s (Kanakoudis, Tsitsifli, 2014). The infrastructure system changed too, with the closing of polluted abstraction points, concentrating of production at just a few points and linking up the networks (Lupton and Bauby, 2008). 


\begin{tabular}{|c|c|c|c|}
\hline Text & Date & $\begin{array}{r}\text { Title } \\
\end{array}$ & Main objectives \\
\hline \multicolumn{4}{|c|}{ European Directives } \\
\hline Directive 75/440/CEE & $06-16-1975$ & $\begin{array}{l}\text { Concerning the quality required of } \\
\text { surface water intended for the } \\
\text { abstraction of drinking water in the } \\
\text { Member States }\end{array}$ & $\begin{array}{l}\text { Norms for abstracted water } \\
\text { quality }\end{array}$ \\
\hline $\begin{array}{l}\text { Directive } 80 / 778 / \mathrm{CEE} \\
\text { Modified by } 98 / 83 / \mathrm{CE}\end{array}$ & $\begin{array}{l}07-15-1980 \\
11-03-1998\end{array}$ & $\begin{array}{l}\text { Relating to the quality of water intended } \\
\text { for human consumption }\end{array}$ & $\begin{array}{l}\text { Upgraded norms for abstracted } \\
\text { water quality }\end{array}$ \\
\hline $\begin{array}{l}\text { Directive } 2000 / 60 / \mathrm{CE} \\
\text { (named EU Water } \\
\text { Framework Directive) }\end{array}$ & $10-23-2000$ & $\begin{array}{l}\text { Establishing a framework for the } \\
\text { Community action in the field of water } \\
\text { policy }\end{array}$ & $\begin{array}{l}\text { Obligatory outcomes } \\
\text { Good ecological state } \\
\text { Water bodies } \\
\text { Full recovery costs } \\
\end{array}$ \\
\hline $\begin{array}{l}\text { Directive } 2006 / 123 / \mathrm{CE} \\
\text { (named Service } \\
\text { Directive) }\end{array}$ & $12-12-2006$ & On services in the internal market & $\begin{array}{l}\text { Strengthen rights of utility users, } \\
\text { promote service quality, and } \\
\text { remove legal and administrative } \\
\text { barriers to developing services }\end{array}$ \\
\hline \multicolumn{4}{|c|}{ French Laws } \\
\hline Law no. 64-1245 & $12-16-1964$ & $\begin{array}{l}\text { On water regulations and allocation, } \\
\text { and combating pollution }\end{array}$ & $\begin{array}{l}\text { Creation of water agencies } \\
\text { Polluter-pays principle }\end{array}$ \\
\hline $\begin{array}{l}\text { Law no. 93-122 } \\
\text { (named Sapin Law) }\end{array}$ & 01-29-1993 & $\begin{array}{l}\text { On preventing corruption, and } \\
\text { transparency in economic life and public } \\
\text { procedures }\end{array}$ & \multirow{2}{*}{$\begin{array}{l}\text { Tender process for water utility } \\
\text { agreement } \\
\text { Rules for agreement provisions } \\
\text { Limits on length of the } \\
\text { agreement (ten to fifteen years } \\
\text { maximum) }\end{array}$} \\
\hline $\begin{array}{l}\text { Law no. 95-127 } \\
\text { (named Mazeaud Law) }\end{array}$ & 02-08-1995 & $\begin{array}{l}\text { On procurement contracts and delegating } \\
\text { public services }\end{array}$ & \\
\hline $\begin{array}{l}\text { Law no. 95-101 } \\
\text { (named Barnier Law) }\end{array}$ & 02-02-1995 & $\begin{array}{l}\text { On strengthening environmental } \\
\text { protection }\end{array}$ & $\begin{array}{l}\text { Improving public information } \\
\text { Annual report on water utility } \\
\text { price and quality }\end{array}$ \\
\hline $\begin{array}{l}\text { Law no. 2006-1772 } \\
\text { (named LEMA) }\end{array}$ & $12-30-2006$ & On water and the aquatic environment & $\begin{array}{l}\text { Powers for local authorities } \\
\text { Possibility to experiment with a } \\
\text { rainwater charge and increase } \\
\text { tariffs for utilities }\end{array}$ \\
\hline Law no. 2010-559 & $05-28-2010$ & $\begin{array}{l}\text { For developing local public companies } \\
\text { (sociétés publiques locales }=\text { SPL) }\end{array}$ & $\begin{array}{l}\text { A new ownership status, akin to } \\
\text { municipalization, but company } \\
\text { subject to private company law }\end{array}$ \\
\hline $\begin{array}{l}\text { Law no. 2013-312 } \\
\text { (named Brottes Law) }\end{array}$ & $04-15-2013$ & $\begin{array}{l}\text { To prepare the transition towards a } \\
\text { sober energy system and support various } \\
\text { provisions on water utility tariffs and } \\
\text { wind turbines }\end{array}$ & $\begin{array}{l}\text { Expand experimental social } \\
\text { tariffs } \\
\text { Water outages banned }\end{array}$ \\
\hline \multicolumn{4}{|c|}{$\underline{\text { Italian Laws }}$} \\
\hline $\begin{array}{l}\text { Law no. 319/76 } \\
\text { (named Merli Law) }\end{array}$ & $05-10-1976$ & $\begin{array}{l}\text { Framework legislation for } \\
\text { environmental protection and regulation } \\
\text { of wastewater discharge }\end{array}$ & $\begin{array}{l}\text { Widespread quantitative and } \\
\text { qualitative criteria for } \\
\text { management of water utilities } \\
\text { Regions and municipalities } \\
\text { responsible for controlling, } \\
\text { planning at the local level }\end{array}$ \\
\hline $\begin{array}{l}\text { Law no. 36-1994 (named } \\
\text { Galli Law) }\end{array}$ & 01-05-1994 & Provisions governing water resources & $\begin{array}{l}\text { Aggregation of municipal utilities } \\
\text { into single territorial units } \\
\text { (Ambito Territoriale Ottimale) } \\
\text { Servicio Idrico Integrato } \\
\text { Principle of cost recovery by } \\
\text { revenues } \\
\text { Improvement of service quality }\end{array}$ \\
\hline Law no. 183/1989 & 05-18-1989 & $\begin{array}{l}\text { Rules for the organizational and } \\
\text { functional reorganization of soil } \\
\text { preservation }\end{array}$ & $\begin{array}{l}11 \text { national basins, managed by } 6 \\
\text { basin authorities and } 18 \text { inter- } \\
\text { regional and regional basins }\end{array}$ \\
\hline $\begin{array}{l}\text { Legislative decree no. } \\
152 / 2006\end{array}$ & 04-03-2006 & Environmental standards & $\begin{array}{l}\text { Transposition of hydrographic } \\
\text { districts and water planning }\end{array}$ \\
\hline
\end{tabular}

Table 1 - Water utilities in France and Italy: overview of directives and laws (since 1970) 


\subsection{Managing and paying for water utilities: some differences between countries}

The situation in France and Italy differs with regard to water pricing and willingness to pay for water utilities. Concretely, the water unit price in Italy is rather low for Europe ( $€ 2.80$ per cubic meter in average). In France, the unit price (€3.50 per cubic meter in average) includes two specific taxes for water agencies, one for "water resource preservation", and another for "tackling pollution". The major difference between the two countries is the existence of six water agencies in France, set up by a 1964 law (table 1). The water bill includes a fee that users pay to their respective agency. They provide funding for local water protection projects and infrastructure renewal, supplemented by regional funding for investments in water utilities and service improvements. This financial mechanism leads to water being more expensive in France than in Italy, though on its own it does not fully explain the price gap. These environmental charges exist in several EU countries, though admittedly not that many (see box 1).

Box 1 - Water extraction charges

Since the mid-1990s, several European regions and countries have introduced water extraction charges. Several German Landers (including Baden-Wurttemberg) apply charges to the extraction of underground and surface water, with surface water attracting different rates depending upon its usage (the highest charge being for drinking water). In the Netherlands charges apply to underground water extraction, with a reduced rate for industry and agriculture. In Denmark, only water for domestic consumption is subject to extraction charges. Whether in France or in these other countries, drinking water is charged at a higher rate than other usages, triggering recurrent debate.

Source: Flory, J.C., 2006. La gestion de l'eau: perspective française et exemples européens Problèmes économiques n ${ }^{\circ} 2900,24 / 05 / 2006$, p.2-9.

Paying for water utilities is now fairly widely accepted in France. "Water income for water utilities" is an economic principle that receives broad social support, having been established for a very long time. Utilities payment was first introduced in France in the middle of the $19^{\text {th }}$ century, when private firms (Compagnie Générale des Eaux, Lyonnaise des Eaux) started investing in large towns, as waterworks firms had done in England in the $17^{\text {th }}$ century (Defeuilley, 2016). From the beginning of $20^{\text {th }}$ century, publicly owned companies-hence the municipalities - proceeded to implement a paid service system (Lupton, Bauby, 2008). More generally, the various forms of Public-Private Partnerships (PPP) around the world are based on contractual agreements between public authorities and private companies. In the EU, the management of water provision is ensured either by not-for-profit PPPs (in Austria, Denmark, and Sweden), or by mixedscheme PPPs (in France, Belgium, Finland, Spain, Germany, and Italy). Water provision in England and Wales has been privatized since 1989, whilst in Greece and the Netherlands it is publically managed (Kanakoudis, Tsitsifli, 2014). In 
France, it is estimated that water utilities currently amount to around 1\% of household budgets in France. But the average price conceals extensive variability, and price increases are a sensitive issue: between 1991 and 2000, water price in average has raised from $€ 1.56 €$ to $€ 2.65$ (Fauquert, Montginoul, 2011).

In Italy, water catchment, transportation, and distribution, and wastewater collection and treatment are an integrated service, il Servizio Idrico Integrato. Under the Galli law (1994), integrated water utilities underwent were reorganized into optimal territories (Ambito Territoriale Ottimale, ATO), managed by a local public authority (Autorita d'ATO, AATO). Each region is divided into several ATOs, with each ATO being managed by a single company, which applies its own tariffs. The municipal authorities have "considerable freedom in choosing the organizational structure of the water supply and sanitation operation (publicowned company, public-private partnership, or delegation to a private operator)" (Breuil et al., 2005).

The water tariff does not result solely from economic computation, though managers do attempt to better individualize service costs through close knowledge of the cost of basic technical tasks (Guérin-Schneider, Nakhla, 2003). Pricing is regulated by specific institutions and, in both France and Italy, is influenced by political decisions. For instance, the municipality votes on the water tariff each year, in accordance with any terms in the delegation agreement. Thus the principle of full-cost recovery is offset by a whole series of other objectives and considerations, including equality, fairness, and public and political acceptability (Boland, Whittington, 2000; Barraqué, 2012). In this context, the single tariff harmonization at regional or local scale is an international issue. In the US in 1999, single-tariff pricing was broadly accepted by 8 state public utility commissions, with 17 further commissions adopting it on a "case-by-case" basis. The other 26 commissions have either never considered it or deem it is not applicable, whilst in certain other states there is no public utility commission (US EPA, 1999). In addition to arbitration by local authorities, certain common trends may be observed in both France and Italy, relating to tariff structure and to territorial policies.

\section{Spatial tariff harmonization. A shared ambition, with specific factors and processes}

\subsection{Two case studies and their territorial organizations}

It is now time to turn to the two case studies, and present their respective stakeholders, territories, and technical data. Table 2 presents the main data for comparison. The cases are Bassin Rennais SPL in Brittany, and Alto Valdarno ATO in East Toscana. The territories of each are organized around a major town: Rennes (200,000 inhabitants), and Arezzo (100,000 inhabitants). The number of subscribers is of the same order of magnitude, as are the number of communes 
and the volume produced, standing respectively at 24 million and 20 million cubic meters.

\begin{tabular}{|l|c|c|}
\hline & Bassin Rennais & ATO Alto Valdarno \\
\hline Surface area $\mathbf{( k m}^{\mathbf{2}}$ ) & 1020 & 3272 \\
\hline Communes & 56 & 36 \\
\hline Number of subscribers & 194345 & 156250 \\
\hline $\begin{array}{l}\text { Volumes produced (million } \\
\mathbf{m}^{3} \text { ) }\end{array}$ & 24 & 20 \\
\hline Volumes invoiced (million $\mathbf{~ m}^{\mathbf{3}}$ ) & 23 & 15 \\
\hline Pipe length (km) & 3707 & 3444 \\
\hline Abstraction points & 12 & 370 \\
\hline Purification stations & 7 & 52 \\
\hline Water leakages (\% total) & 9 & 30 \\
\hline Water supply owner & $\begin{array}{c}\text { SPL Eau du Bassin rennais } \\
\text { (public local company) }\end{array}$ & $\begin{array}{c}\text { Nuove Acque SPA } \\
\text { (semi-public company) }\end{array}$ \\
\hline
\end{tabular}

Table 2 - Case studies of France-Italy: baseline data

The Bassin Rennais owner changed recently. From 1882 to 1995 , a multinational French group, Véolia Company, was the delegated owner of water utilities for the town of Rennes and part of the Rennes catchment area. When the agreement lapsed in 2015, the municipal council put water supply management out to tender. It decided to delegate it to a type of body called a local public company Société Publique Locale (SPL) for a 15-year period, with sewerage being managed separately. By law (table 1), an SPL is $100 \%$ publicly and directly manages the utility, despite being subject to private company law. The delegate owners in Italy were also selected by tender. The infrastructure performance indicators for Bassin Rennais SPL are good, thanks to its long-standing experience: water leakages are under $10 \%$, and income corresponds to forecasts. The main issues relate to river water quality (with organic matter, nitrogen, phosphorus, pesticides), and managing shortages, as in many regions in Europe.

AATO Toscana has delegated integrated waterworks to six companies. These companies are jointly owned by public authorities and private companies (with one exception). The level of private ownership is below 50\%, ranging from $40 \%$ to $48 \%$. Toscana Law 69/2011 allows for there to be a single water provider for the region by the end of the delegation period (running from 2021 to 2034, with 5 agreements out of 7 to lapse between May 2024 and December 2025). The Alto Valdarno ATO, created in 1997, delegated water supply and sanitation management to Nuove Acque Company, for a 25-year period commencing June 1, 1999. The length of the delegation agreement ( 25 years) is justified on the grounds that five years were needed to conduct the diagnosis and draw up a program of works. Nuove Acque is jointly owned by the public authorities, with $53.84 \%$ held by the commune di Arezzo, and $46.16 \%$ held by a private company, Intesa Aretina Scarl, of which $61 \%$ is owned in turn by the French group Suez-Lyonnaise des 
Eaux, Véolia's competitor in France and worldwide. Intesa Aretina Scarl was founded with the sole purpose of setting up Nuove Acque (Nuove Acque, 2016). Financial decisions by Nuove Acque and Bassin Rennais SPL are influenced by local politicians, directly in the case of the former, indirectly for the latter. For Alto Valdarno ATO, water leakages currently stand at around $30 \%$, and revenue shortfalls (of $30 \%$ ) are a major issue for the utilities companies, with around 5 million cubic meters going unpaid for. An infrastructure diagnosis has been carried out, but the renewal of old pipes is only slowly gathering pace due to the high costs involved. The first step for the owner is to secure water supply 24/7. In some tourist areas, such as Casentino and Pratomagno, water tankers are required to cover summer shortages.

The first stage in rationalization is individual billing. Table 3 presents the tariff framework for Alto Valdarno ATO. In particular, the invoice includes the water supply price (production, transportation and distribution) and the sanitation price (collection and treatment), whereas in France supply and sanitation are managed by separate companies. Sanitation is paid at a fixed rate per cubic meter, while the price for water supply varies with the volume consumed. Nevertheless, there are significant similarities between water invoicing structure in France and Italy. Between 2012 and 2013 in France, the price of water supply rose by $0.5 \%$, and that of sanitation by $3.8 \%$. The proportion for sanitation has increased, now amounting to over $50 \%$ of the total bill (source: Eau France). A similar trend is observable in Italy. Furthermore, in both countries there is a "two-part tariff", that is to say a fixed part (the same for all service users) and a variable component (depending on the volume consumed and the unit price per cubic meter). This indicates the implementation of an EU framework for water management. This two-part tariff has received backing from researchers, who identify many benefits: "it is simple and transparent, easy to implement, more likely to produce net revenue stability, and consistent with resource conservation objectives" (Boland, Whittington, 2000).

\begin{tabular}{|c|c|c|c|c|c|c|}
\hline Cubic meter & $0-30$ & $31-80$ & $81-150$ & 151-200 & +200 & Fixed part \\
\hline Water supply & $€ 0.636634$ & $€ 1.126355$ & $€ 1.351627$ & $€ 3.525989$ & $€ 5.166553$ & $€ 23.225866$ \\
\hline $\begin{array}{c}\text { Wastewater } \\
\text { collection }\end{array}$ & & & $€ 1.019139$ & & & $€ 14.622988$ \\
\hline $\begin{array}{c}\text { Wastewater } \\
\text { treatment }\end{array}$ & & & $€ 0.421657$ & & & $€ 5.290169$ \\
\hline
\end{tabular}

Table 3 - Alto Valdarno ATO (Italy) - Tariff framework on December 15, 2016 (excluding state charge, named IVA) 


\subsection{A local or a regional regulation?}

The water price structure is regulated to different degrees in France and Italy, due to the different institutional set-ups. In France, water utilities management has long been a municipal responsibility, frequently transferred to inter-municipal bodies. The price structure is determined locally in a decentralized framework, though overseen by the state (through laws, observatories, legal oversight, and so on). This "implicit regulation" is deemed simple to implement (Crespi-Reghizzi, 2013). In Italy, water prices are supervised by a national body, the Italian Regulatory Authority for Electric, Gas and Water (Autorità per l'Energia Elettrica, il Gas e il Sistema Idrico (AEEGSI), based in Milan. This regulatory body, set up in 1996, has overseen water price regulation since 2012, when it replaced in the Agenzia nazionale per la regolazione e la vigilanza in materia di acqua. The AEEGSI fixes the method for computing fixed and variable tariffs. Then the regional Autorità Idrica Toscana (AIT), based in Florence, determines the prices and service rules for each user category. The AIT fixes a range for the annual price increase, taking into account planned investments and service indicators (leakages). It then negotiates the specific price increase with each water company in Toscana. Currently they all apply a different price. This will temporarily continue to be the case, in accordance with the indicators and the investments carried out.

\subsection{The new policies about tariff water harmonization and the inter municipalities' involvement}

Let us now turn to policies for the convergence of water utility pricing, and their outcomes. Local authorities have launched the harmonization of water utility prices under various legal frameworks. In France, new utility pricing strategies have been tried out since the 1990s thanks to the increased know-how and powers of inter-municipal bodies. Harmonization in water utility pricing has been accompanied by the rationalization of water quality services (Nantes) and of investment funding (Rouen).

In the first example, Nantes (450,000 inhabitants), it is the metropolitan authority (communauté urbaine) that has been in charge of water supply and sanitation since January 1, 2001, when it replaced 33 administrative entities (with 48 different prices). Since then, it has harmonized the prices applied by public operators (covering $50 \%$ of users) and by the 24 delegated operators. In the second example, Rouen (350,000 inhabitants), water supply and sanitation has been run by the metropolitan authority area since January 1, 2005. There are 12 different suppliers with varying prices (ranging from $€ 109$ to $€ 190$ per 120 cubic meters). The objective is a uniform price at the lowest existing level. This process will be supported by expanding public management as delegation agreements lapse over time. Other examples include Montpellier (with a single tariff for ten communes since 2011) and Dijon (where there has been tariff convergence since 2011). Some 
French departments are working to reduce disparities between municipal prices, which can range from $€ 0.5$ to $€ 6$ per cubic meter.

In France, the law has recently opened up new possibilities for local authority commodity policies. The December 2006 LEMA law on water and aquatic environments (table 1) encourages local authorities to apply a progressive tariff. The aim is twofold: social access for low revenue households and limiting resource consumption for environmental reasons. Declining tariffs are banned in places of recurrent shortages. In preparation for the law on energy transition for green growth (August 2015), the April 2013 Brottes law (table 1) has enabled cities to apply a social tariff structure for a five-year period, together with welfare assistance for water bills. The number of cities experimenting with this scheme rose from 18 in May 2013 to 50 in August 2015. The experiment will come to an end in April 2018, when it will be assessed. The government has declared that 'the most relevant solutions may be extended, if appropriate, to the whole country".

Generally speaking, the local authorities involved in the scheme have developed three types of mechanism, though not necessarily applying all three: a free consumption band for the first 10 or 15 cubic meters, revenue-based welfare assistance, and a reduction for large families (supporting documentation is required for these last two measures). Certain authorities have simultaneously launched price convergence across their inter-municipal zone, as was the case in the Bassin Rennais SPL (which is involved in the national experiment). In February 2015, local public authorities studied several scenarios for social tariffs and tariff convergence. Bassin Rennais managers and elected representatives highlighted the price differences in the metropolitan area, ranging from $€ 2$ to $€ 4$ per cubic meter for supply and sewerage. Table 4 presents the pricing structure for one municipality, Rennes, where the price is low in comparison to elsewhere in the Bassin rennais as a whole. Certain disparities (already mentioned in section 2) stem from rational factors, such as water quality, user density, infrastructure length, pace of infrastructure renewal, lack of competition and oversight, and so on. The declared target of the water utility owner is a uniform price across the entire Bassin Rennais zone, that is to say for all 56 communes, by the end of current delegation agreements (in 2020). Amendments to ongoing agreements are also possible. The target price is between $€ 2.18$ and $€ 2.21 €$ per cubic meter (for supply and sewerage). Convergence to a uniform price for all 56 communes should occur by 2025. In November 2017, only the block rate pricing structure was harmonized across 28 communes, covering nearly 50,000 subscribers: the 10 first cubic meters are free, and the unit price rises in blocks (11 to $100 \mathrm{~m}^{3}, 101$ to $150 \mathrm{~m}^{3}$, and over $150 \mathrm{~m}^{3}$ ) (table 4). 


\begin{tabular}{|c|c|c|c|c|c|}
\hline Cubic meter & $\mathbf{0 - 1 0}$ & $\mathbf{1 1 - 1 0 0}$ & $\mathbf{1 0 1 - 1 5 0}$ & $\mathbf{+ 1 5 1}$ & fixed part \\
\hline Water supply & 0 (free) & $€ 1.49$ & $€ 1.75$ & $€ 2.36$ & $€ 24.08$ \\
\hline $\begin{array}{c}\text { Wastewater } \\
\text { collection and } \\
\text { treatment }\end{array}$ & 0 (free) & $€ 1.26$ & $€ 1.44$ & $€ 1.78$ & $/$ \\
\hline $\begin{array}{c}\text { Taxes Water } \\
\text { Agencies }\end{array}$ & $€ 0.519$ & $€ 0.526$ & & $/$ \\
\hline
\end{tabular}

Source: Eau du Bassin Rennais

Table 4 - Rennes (France) - Tariff framework on November 15, 2017 (excluding state charge, named TVA)

However, this ambitious process has to meet several requirements and has run into various obstacles. First, the public owner wishes to ensure that SPL revenues are stable, while also complying with the stakeholders' agreement (subscribed to by elected representatives and associations) and adhering to the "Ecodo" scheme to save water (that was launched ten years ago and has been quite effective). Second, it must cap the rise in unit price to meet the user expectations in communes with low prices. Third, this economic rationalization has led to a drop in owner revenue. This aspect is not problematic for a public owner, who does not seek large profits, but it still needs to take it into account in its financial management.

In Italy, the price remains relatively low, with a concomitant impact on investment (Crespi-Reghizzi, 2013). National regulations encourage companies to improve their productivity and efficiency (Crespi-Reghizzi, 2013). The Galli law created large water management territories, the ATOs, which are fairly centralized, though local cooperation is slower. The principle underpinning the Galli Law is a uniform tariff within each ATO (in Toscana) based on full-cost recovery, establishing water utilities as an industrial sector (Mangano, 2012). "Another principle is to define a tariff system based on the same price for each ATO” (Breuil et al., 2005, p.231). The problem of conflicts of interest is especially strong in the water, waste, and transportation sectors, for despite the involvement of national and regional authorities, the municipalities are the only real regulators (Argento et al., 2010). A major campaign by associations and citizens groups (the Italian Forum for Water Movements) triggered a referendum about water utilities in June 2011. This resulted in the abrogation of two provisions in the Ronchi decree (2009), particularly the obligation for local authorities to delegate water utility management to public, private, or jointly owned companies by the end of year (Massarutto, 2012). In this way, despite the implementation of a new system in the 2000s (with water payments being used to improve infrastructure), citizen and user groups espoused an opposite view to that held by water utilities, being clearly attached to public management.

Tariff equalization mechanisms to produce a uniform local price in Italy and France are complex. This process exceeds a rationale based solely on cost. Hence local authorities drop the strict enforcement of cost-recovery through pricing. 
Prices and user subscriptions are pooled at a larger scale. Such a pricing system is difficult to build, despite the overhaul of water utility zoning in France and in Italy.

\section{Concluding remarks}

Price congruence is a pragmatic strategy in which economic and political levers can combine to deliver a social tariff. But operators and users may view it differently. While introducing a visible change in subscriber behavior, the financial mechanisms remain complex and "in-house". It should be noted that while this paper looks primarily at the variable price component (the price per $\mathrm{m}^{3}$ ), "the case of the fixed charge is an interesting issue and should be re-examined" (Kanakoudis, Papadopoulpou, Tsitsifli, 2015).

\subsection{The economic and socio-political issues}

An important topic is the use of financial mechanisms to offset losses in revenue for private owners when the water price decreases. How are the resultant economic burdens to be distributed? Although the price decreases in some communes, it increases in others. If this involves different delegated operators, redistribution is a tricky issue. In contrast, the transition to a uniform price may be easier under a unified public owner, who can implement cross-subsidies while benefiting from economies of scale. In France, the municipal budget cannot be used to support this type of operation: the water supply budget is separate from the sanitation budget, and each must balance. In both France and Italy, the harmonization process must take into account the timeframe of the delegation agreements, their renewal, and even the negotiation of riders to these agreements. Whatever the process, it may be concluded that a single price across a metropolitan area is an asset for water utility customers (it is simple), but opaque in terms of economic assessment (since it may contain hidden costs).

Furthermore, price convergence can give rise to ethical and socio-political debate. Indeed, political strategy transcends the "true cost" principle, supporting harmonization on other grounds, namely social and spatial equality. The principle of subsidiarity may allow for this type of decision at local management scale. Yet at the same time, it is the state that acts as the regulatory instance. The Brottes law in France has enabled several cities and local authorities to conduct an experiment, but without any decision about possible follow-ups yet. It will probably be beneficial to pursue several of the ongoing policies. The government will be an incentivizing actor in the development of "good practice". But the question remains of the number of the local authorities and cities willing to pursue this type of policy.

In the context of powerful regions in Italy, regulatory bodies supervise water utility pricing and any price increases. Prices are currently decided locally, after negotiations between the local company and the municipalities. The Italian model 
is not yet stabilized. "One expected outcome of the reform is to develop the water and wastewater services in the rural areas around the urban areas thanks to the unique tariff' (Breuil et al., 2005, p.220). The question remains of whether the restructuring of ownership in the wake of the Galli law will lead to major changes in management.

Above and beyond the difficulties in effecting price convergence, progressive pricing by block rates appears to be increasingly common in the European countries studied. Even though the block thresholds differ, the principle remains the same, making it possible to try to recover costs by revenue from subscribers in the upper brackets. In the 2000s in the United States, on the other hand, this was a minority model for water supply pricing. Indeed, a large survey by EPA Community Water System in 2000 (over 1200 systems) showed only 9.2 per cent of systems employing increasing block rates (US EPA, 2003).

\subsection{The key role of the local level}

In the geographical approach set out here, the topic of the appropriate scale for experimenting and implementing new pricing policies is another major issue. In France, price convergence is possible at city scale, though calls by an NGO such as the Local Confederation of Living Conditions (CLCV) for a national price are not realistic. The departments can promote tariff harmonization within their territory, but the number of utility owners and of inter-communal groupings complicates the process. The regions have no expertise in running water utilities, only in resource protection. In the wake of their expansion as part of the restructuring of French regions in 2016, they are unable to manage such projects. The most appropriate scale may be the local level, where an authority controls the economic parameters and wishes to consolidate its power. The SPLs and public owners in France, like the public-private companies in Italy, are potentially interested in this type of strategy. Our interlocutors saw the advantage of equality, for though it entails many negotiations and delays it strengthens public authority. A further, strategic issue is providing consistent quality for all the water services (drinkability, pressure, reliability, uninterrupted service, etc.).

The local scale is also relevant for social movements, which have brought together political parties, trade unions, non-governmental organizations, and ecological associations in several towns across France. Their leaders have met practitioners and researchers in workshops and conferences. By drawing on national and transnational resources they have acquired knowledge and developed skills in the field of water utilities. They now constitute a network promoting public debate and exerting pressure on local elected representatives. In the example of Rouen, in section 3, an activist citizen coalition of this kind called for water utilities to be run by the metropolitan authority. Their return to public ownership and price convergence is a result of this collective action, as respondents indicated in triangulated interviews. 


\subsection{Views for further research}

Lastly, let us resume the main points made, and suggest areas for further research. The overview presented here has highlighted several trends common to the two case studies, France and Italy, in line with the EU standardization of water pricing structures. The differences arise from different national regulations and territorial models. France has a tradition of inter-municipal bodies, while in Italy ATOs are controlled by regions. France has a history of large firms and payment for water utilities. That differs from the situation in Italy, based on a recently introduced payment system, with lower unit prices set by national and regional authorities. Equally, the forms of coordination and cooperation in Italy are hierarchical and network-based rather than participatory, meaning that the conditions are not yet in place for introducing territorial price equality.

The larger context needs further examination, drawing on surveys of institutions and practitioners, and expanding the framework to include customers' perception of tariffs. Most people probably fail to perceive any pattern between territorially uniform prices and tariff increases. Furthermore, as mentioned earlier, experiments with water pricing harmonization have been limited to a five-year period (20132018) and only involve fifty towns in France. This paper will therefore be followed up by assessment looking primarily at French towns the experiment in 2018 (including the Bassin Rennais SPL). Local surveys of how convergence processes are perceived will help understand the impact (or absence of impact) on users'/customers' attitudes. Is the user aware of this change? Are subscribers interested in the question? How do the public authorities and private owners communicate about these changes? Although the literature tends to view user price as fairly inelastic, this analysis will investigate qualitative perceptions of the equalization of service pricing with regard to other regional cases and studies (Kanakoudis et al., 2016). It needs to be determined to what extent "regional communities" can be built on price levels which not only issue from political and economic compromises, but at the same time signify the social value of water supply.

\section{Acknowledgements}

The author is very grateful to all those interviewed in Italy and France. I also wish to thank Marina Marengo (Siena University) for her support and translation from Italian into French. This article has received financial support from the ANR "Makara" program and from University Rennes 2

\section{References}

Argento, D., Grossi, G., Tagesson, T., Collin, S.-O., 2010. The externalization of local public service delivery: experience in Italy and Sweden. International Journal of Public Policy, vol.5 no. 1, 2010, 41-56. 
Autorità Idrica Toscana, 2015. La regolazione del servizio idrico in Italia e l'Autorita Idrica Toscana, Area Regolazione, AIT, Pisa, 13 marzo 2015.

Bakker, K., 2007. The "Commons" Versus the "Commodity": Alter-globalization, Antiprivatization and the Human Right to Water in the Global South. Antipode 39/3, June 2007, 430455.

Barraqué, B, Juuti, S. P., Katko, T. S., 2012. Urban water conflicts in recent European history: changing interactions between technology, environment and society, in: Barraqué B. (ed.), Urban water conflicts, UNESCO-IHP Urban water series no. 8, 15-32.

Bauby, P., Similie, M.M., 2013. Quelle européanisation du service public de l'eau?, in: Pecqueur B. et Brochet A. (eds.), Le service public d'eau potable et la fabrique des territoires, Paris, L'Harmattan, 97-106.

Beecher J.A., et al., 1994, Revenue effects of water conservation and conservation pricing : issues and practices. National Regulatory Resaerch Institute, Colombus $\mathrm{OH}$.

Boland John, J., Whittington, D., 2000. Water tariff design in developing countries: disadvantages of increasing block tariffs (IBTs) and advantages of uniform price with rebate (UPR) designs. Bank water and sanitation program, Baltimore, Chapel Hill, 37p.

Breuil, L., Canneva, G., Garcia, S., 2005. Country Report Italy, in Euromarket, in: Water liberalisation scenarios. Projet Euromarket Water, European Commission, FP5, 194-233.

Crespi-Reghizzi, O., 2013. Institutions, comptabilité et financement des services d'eau et d'assainissement en Italie et en France, Congrès de l'ASTEE (Association de Sciences et Techniques pour l'Eau et l'Environnement), Nantes (France).

Defeuilley, C., 2017. L'Entrepreneur et le Prince. La création du service public de l'eau. Paris, Presses de Sciences Po, 328p.

Euromarket Project, 2005. Water Liberalisation Scenarios, European Commission, FP5, EUROMARKET EVK1-CT-2002-00113. https://www.ecologic.eu/877

Fauquert, G., and Montginoul, M., 2011. Composantes du prix de l'eau: quells objectifs pour quells prix, in Bouleau G., Guérin-Schneider L.(eds), Des tuyaux et des homes. Les réseaux d'eau en France, Quae: 101-119.

Garcia-Valiñas, M., Picazo-Tadeo, J. A., 2015. Introduction to reforming water tariffs: experiences and reforms. Utilities Policy 34/2015, 34-35.

Grafton, R. Q., Chu, L., Kompas, T., 2015. Optimal water tariffs and supply augmentation for cost-of-service regulated water utilities. Utilities Policy 34/2015, 54-62.

Guérin-Schneider, L., Nakhla, M., 2003. Les indicateurs de performance: une évolution clef dans la gestion et la régulation des services d'eau et d'assainissement. Flux 2003/2 (no. 52-53), 55-68.

Guérin-Schneider, L., Lorrain, D., 2003. Note de recherche sur une question sensible. Les relations puissance publique-firmes dans le secteur de l'eau et de l'assainissement. Flux 2003/2 (no. 52-53), $35-54$.

Kanakoudis, V. and al., 2016. Determining a socially fair drinking water pricing policy: the case of Kozani, Greece, Procedia Engineering, 162:486-493, Elsevier.

Kanakoudis, V. and K., Gonelas, 2014. Forecasting the Residential Water Demand, balancing the full water cost pricing and the Non-Revenue Water reduction policies: the case of Kozani city in Greece, Procedia Engineering, 89:958-966, Elsevier.

Kanakoudis, V. and S., Tsitsifli, 2014. Doing the urban water supply job: from privatization to remunicipalisation and the third pillar of the Performance Based Service Contracts, Water Utility, (6):31-46, EWRA.

Kanakoudis, V., Papadopoulpou A., Tsitsifli S., 2015. "Domestic water pricing in Greece : a spatial differenciation“, Desalination \& Water Treatment, Taylor \& Francis, 54(8): 2204-2211.

Le Galès, P., 2011. Policy Instruments and Governance, In: The SAGE Handbook of Governance, edited by Mark Bevir, SAGE Publications Lt,.142-160.

Lupton, S., Bauby, P., 2008. Directives européennes sur la qualité de l'eau et montée de la délégation du service d'eau potable en France. Cosmopolitiques no. 17,173-190. 
Mangano, A., 2012. Water services in Italy: scale economies and sustainability, 20/11/2012, Seminar ANR Eau \&3E "European water and sanitation services". Athens Week (Greece), 24p. Massarutto, A., 2012. Urban water reform in Italy: A live bomb behind outward unanimity, in: Barraqué B. (ed.), Urban water conflicts, UNESCO-IHP Urban water series no. 8, 247-268.

Melosi Martin, V., 2012. Full circle? Public responsibility versus privatization of water supplies in the United State, in: Barraqué B. (ed.), Urban water conflicts, UNESCO-IHP Urban water series no. 8, 40-56.

Motta Sarah C., Nilsen Alf Gunvald (eds.), 2011. Social Movements in the Global South, Disposession, development and resistance. Basingstoke, Palgrave Macmillan, 275p.

Nuove Acque, 2016. Bilancio di sostenibilida 2015, 148p.

Rogers, P., De Silva, R., Bhatia, R., 2002. Water is an economic good: How to use prices to promote equity, efficiency, and sustainability. Water Policy 4/2002, 1-17.

Romano, G., Guerrini, A., Campedelli, B., 2015. The new Italian water tariff method: A launching point for novel infrastructures or a backwards step? Utilities Policiy 34/2015, 45-53.

Roth E., 2001. Water pricing en the EU. A review. European Environment Bureau, Brussels, $2001 / 002$.

Smets, H., 2013. Nouveaux tarifs pour l'eau potable / New tariffs for drinking water. Paris, Johanet, 231p.

SPL Eau du Bassin Rennais, 2016. Rapport annuel sur le Prix et la Qualité des Services d'eau potable. Exercice 2015, 171p.

U.S. Environmental Protection Agency, Office of wastewater management, 2003. Water and Wastewater Pricing. An Informational Overview. EPA 832-F-03-027, 10 p.

U.S. Environmental Protection Agency, Office of water, 1999. Consolidated water rates: issues and practices in single-tariff pricing. September 1999, Washington DC, $122 \mathrm{p}$.

Van de Meene, S.J., Brown, R.R., Farrelly, M.A., 2011. Towards understanding governance for sustainable urban water management. Global Environmental Change, vol. 21, issue 3, Elsevier, $1117-1127$. 